\title{
АНТРОПОЛОГИЯ ДОСУГА ЖЕНЩИН В ГДР
}

В статье рассматриваются антропологические особенности досуговых практик женщин в Германской Демократической Республике. Свободное время женщин в условиях тоталитарного общества автором характеризуется как квази-досуг, условно разделённый на публичный, связанный с государственными массовыми мероприятиями, и личный, содержание которого в большей степени определялось женщинами. Выделен ряд факторов, обуславливавших объём времени, свободного от трудовой и общественной деятельности. Анализ таких источников, обладающих высокими информаџионными возможностями, как женская периодическая печать и семейные кинохроники ГДР, позволили выявить аспекты нормирования досуговых практик со стороны государства и характер отклика общества на методы пропаганды. Женская пресса рассмотрена как механизм транслячии нормативного образа женщины, вылвлены содержание и специфика публикаций, посвящённых свободному времени, различных по содержательному направлению журналах. Привлечение семейных кинохроник, опубликованных в Интернете в рамках спечифичного для ГДР проекта «Ореп тетогу bох» позволило выделить наиболее распространённые и определяемые как значимые формы досуговых практик женщин, среди которых уникальная немецкая традиџия Freikörperkultur (культуры свободного тела), сохранившаяся при сочиализме. Пространство реализаџии досуга в таких формах, как внешний и внутренний туризм, а также отдых на даче рассмотрено в контексте стратегий подчинения и своеволия на фоне ограничений свободы передвижения в условиях диктатуры СЕПГ. Особое внимание уделено трансформащии праздничной культуры в отночении традиционных для Германии фестивалей, а также внедрению "новых" сочиилистических праздников, в том числе альтернативных форм обрядов жизненного изикла, среди которых получивший широкое распространение обряд посвящения молодёжи. Также на основе привлечения женской периодической печати и семейных кинохроник проанализированы значимые для международного имиджа характеристики ГДР, как "читающей страньл" и "спортивной наџии".

Ключевые слова: досуг, история досуга, антропология досуга, женский досуг, женская повседневность, женская история, ГДР

Досуговые практики - один из маркеров повседневной жизни. Как часть культурного пространства они выражают принадлежность носителя к традиции, являются одним из множества факторов коллективной идентичности. Нормирование сферы

Тюренкова Дарья Олеговна - аспирантка, Тверской государственный университет (170100 Тверь, ул. Желябова, 3). Эл.почта: d.tyurenkova@yandex.ru. Tyurenkova, Darya O. - PhDstudent, Tver State University (Tver, Russia). E-mail: d.tyurenkova@yandex.ru 
досуга - важный регулятор поведения человека в рамках тоталитарного общества, в частности - общества в ГДР. В современных гуманитарных исследованиях сложно выявить единую трактовку термина досуг, что связано как с трансформацией его дефиниции с течением времени, так и с различными подходами научных дисциплин к его определению. Проблема применения и осмысления понятия досуг в отечественных исследованиях в рамках междисциплинарного синтеза - в этнологии и социальной антропологии, социологии, истории, - рассмотрена достаточно подробно (Понукалина 2017: 83-89; Сидорчук 2015: 174-186). В целом, исследователи определяют его в рамках дихотомии труд - досуг, относя к последнему совокупность практик, направленных на отдых и развлечения. Ряд авторов исключает из сферы досуга домашние обязанности и общественную занятость, другие же причисляют их к общему объёму свободного от профессиональной деятельности времени (Dumazedier 1974). Однако большинством исследователей признаётся необходимым учитывать весь комплекс занятий вне рабочего времени при определении особенности изучаемого объекта и обстоятельств развития досуговых практик. Исследование досуга в рамках женской истории также ставит проблему содержания термина и соотношения собственно свободного времени женщины и “неоплачиваемого женского труда” в зависимости от широкого спектра социально-культурных и экономических факторов.

В рамках данной статьи под досугом (в нем. Freizeit - свободное время, Erholung отдых) понимается совокупность поведенческих практик, реализуемых женщинами в ГДР в свободное от трудовой деятельности время. Однако тотальный контроль государства над личностью в ГДР позволяет определять указанные практики как квази-досуговые, предписанные со стороны Социалистической единой партии Германии (СЕПГ). Принимая во внимание особенности проживания повседневной жизни в условиях диктатуры, представляется корректным выделить условно публичный досуг, связанный с регламентированной общественной активностью (участие в общественных торжествах, митингах, демонстрациях), и условно личный досуг, практики которого в большей степени допускали возможность выбора женщинами предпочтительных форм проведения свободного времени. Однако важно отметить - деление на публичный и личный досуг условно, т.к. все практики досуга в той или иной степени находились под государственным контролем, зависели от системы инфраструктуры и тех возможностей, которые могли быть реализованы в социалистическом государстве.

В рамках гуманитарных исследований в зарубежной науке различные аспекты досуговых практик подробно проработаны в ряде исторических, антропологических, этнологических и социологических исследований. Наибольший пласт работ создан в объединённой Германии, где тема повседневной жизни женщин в социалистическом обществе активно обсуждается и демонстрирует тенденции сохраняющейся дискуссии о ГДР. Проблема повседневности в ГДР, в том числе история досуга как значимого аспекта повседневной жизни, становится предметом специального исследования в 1990-е гг. Поворот в исторических исследованиях связан с научной деятельностью А. Людке, Т. Линденбергера, Х. Медика, Л. Нитхаммера и др. Значительную роль в изучении аспектов повседневной жизни при социализме играют исследовательские центры и фонды, созданные в 1990-е гг.: Федеральный фонд исследования диктатуры СЕПГ, а также Центр исследования современной истории в Потсдаме. Стремление к осмыслению прошлого выражается также в возникновении неофициальных, авторских интернет-проектов, таких как «DDR-Geschichte», нацеленных на популяризацию 
истории ГДР. Подобные проекты ставят своей целью фиксацию свидетельств очевидцев, касающихся в том числе досуговых практик и культуры потребления в ГДР.

Оценке мифа об эмансипации женщин в ГДР и их повседневной жизни посвящена работа Г. Будде в сборнике «ГДР: миролюбивое государство, читающая страна, спортивная нация?» (Будде 2017). Ряд глав сборника уделяет внимание досуговым практикам - чтению, любительскому спорту, участию в государственных торжествах. Реализация досуговых практик в условиях привлечения женщин к профессиональной деятельности подробно изучены в ряде работ, созданных в рамках гендерных исследований (Пфау-Эффингер 2003: 78-87) и женской истории (Bock 2000). Необходимо отметить специальное исследование «Женщина в ГДР» (Kaminsky 2016), где понятие досуга рассмотрено в контексте объёма реального свободного времени женщины в Восточной Германии до и после введения 5-дневной рабочей недели.

Аспекты трансформации традиционной немецкой праздничной культуры в ГДР, формирования “новых" социалистических праздников и ритуалов подробно изучены в рамках микро-исторических исследований (Meier 1998; Neubert 1998; Lange 2004). Ряд проблем, связанных с “дехристианизацией” в ГДР и последовавшим изменением в восприятии религиозных праздников, исследован в работах, посвящённых взаимоотношениям церквей и СЕПГ в 1949-1989 гг. (Maser 2000)

В советской исторической науке изучение ГДР велось по нескольким направлениям, но досуговые практики не становились предметом исследования. В 1990-х гг. интерес учёных обратился к сфере женского досуга, однако основное внимание было сосредоточено на женской повседневности и досуге в СССР. В последние десятилетия внимание к истории ГДР в целом связано с деятельностью совместной комиссии по изучению новейшей истории российско-германских отношений, публикациями Института всеобщей истории РАН. Также в ряде работ рассмотрено социально-правовое положение женщин в ГДР и проблема реального равенства (Мухина 2013: 33-35; Хорольская 2016: 89-92). Особую значимость представляет публикация сборника «Повседневная жизнь при социализме: немецкие и российские подходы» (Берендс, Дубина, Сорокин 2015), обобщающего исследовательский опыт специалистов, рассматривающих различные направления социалистической повседневности. Интернациональная дружба девочек по переписке как форма межкультурных коммуникативно-досуговых практик рассмотрена в статье А.В. Беловой, а также в других публикациях автора по данной теме (Белова 2015; Белова 2018).

Таким образом, необходимо отметить, что восприятие в обществе ГДР попыток формирования “новой” социалистической праздничной культуры, гендерные аспекты государственного регулирования досуга требуют специального изучения, наряду с исследованием досуговых практик женщин в ГДР с учётом таких социальных факторов, как класс, величина заработной платы, характер профессиональной деятельности, регион проживания, брачный статус, наличие детей и т.д. В рамках данной статьи предпринята попытка выявить антропологические особенности досуговых практик женщин в ГДР.

Исследование досуга связано со сложностями при работе с источниковой базой. В связи с тотальным контролем государства над личностью в ГДР привлечение источников обусловлено необходимостью выделять два уровня фиксации досуговых практик уровень трансляции нормы со стороны государства и уровень восприятия и интериоризации норм среди женщин в ГДР. Методами государственной регламентации в ГДР 
были обращения лидеров СЕПГ и партий Народного фронта, СМИ, находящиеся под контролем партии, образование и т.д. Однако официальные материалы СЕПГ, протоколы съездов и официальная статистика требуют учитывать тенденциозность в представлении государством данных об “успехах социалистического строительства”, тем более, что эффективность привлечения женщин к трудовой деятельности и сопутствующих этому мер по организации социалистического женского быта в рамках достижения равноправия полов свидетельствовали о результативности государственной политики и нередко становились основой для сравнения с ФРГ. Иначе говоря, постулируемые в обращениях факты демонстрировали то, как должна была выглядеть повседневная жизнь женщин в ГДР, что, само собой, было далеко от реальности не только по причине осмысленного искажения, но по причине игнорирования ряда социальных факторов, дифференцирующих досуг женщин, в первую очередь - объём времени, которое могло быть воспринято как “свободное”. Основным фактором в условиях вовлечения женщин в профессиональную деятельность был тип занятости - полной или частичной, что, безусловно, определяло режим дня в соотношении труд/досуг. Отношение государства к женщинам, выбравшим реализацию в семье и отказ от трудовой деятельности, проявлялось в обличительных статьях в прессе и ярлыках “сверчка за печкой” (Heimchen am Herd) и “паразитки” (Schmarotzerin) (Kaminsky 2016: 14). Кроме того, СЕПГ пропагандировала постоянное повышение квалификации в образовательных организациях или по месту работы. Данные меры в большей степени отразились на временных затратах женщин в 1950-х гг., в период активного привлечения к работе на производстве. Также значительный объём времени должна была занимать общественная деятельность: участие в работе отделений Женского демократического союза Германии, консультационных центров для помощи молодым родителям, собраний родителей учащихся школ и т.д. Так, нередко, время, проводимое женщинами дома, в семье, становилось уже не “второй”, а “четвёртой сменой” их занятости. При этом основным вопросом становился статус занятий, составляющих ведение домашнего хозяйства. Как именно вязание, шитьё, кулинария позиционировались в официальных документах и средствах государственной пропаганды? Исследователи фиксируют, что проблема дефицита обеспеченности населения одеждой, в особенности в 1950-е гг., вынуждала женщин заниматься домашним хозяйством в том объёме, при котором вместо досуга подобные занятия являлись фактическим продолжением рабочего дня. Недостаточный ассортимент одежды и обуви приводили к попыткам приобретать товары на “чёрном” рынке за западные марки. Чтобы остановить этот процесс, в 1962 г. в ГДР по решению Совета министров были открыты магазины “западных” товаров «Ехquisit», для “взыскательного спроса”, однако высокая стоимость делала их приобретение недоступным для многих женщин и возвращала к домашнему шитью как вынужденному занятию.

В рамках печатных СМИ в трансляции “нормативных” занятий женщин ключевую роль играли женские журналы. Тематически женскую периодику можно условно представить по трём категориям: 1) журнал - печатный орган общественной организации («Die Frau von heute», «Für Dich); 2) журнал мод («Pramo», «Modische Maschen», «Berlins Modenblatt», «Mode und Schnitt»); 3) “глянцевый” (в современном понимании) журнал («Sibylle»). Все перечисленные журналы выпускались издательским домом «Verlag für die Frau», фактически находящимся в государственной собственности с 1948 г., т.е. под управлением СЕПГ. Наряду с различными женскими журналами издательство также публиковало книги, посвящённые ведению домашнего хозяйства - тематические кули- 
нарные брошюры и кулинарные книги (Feines Gebäck zu Kaffee und Tee 1961; Kochen für junge Leute 1966; Unser großes Kochbuch 1970; Süßes: Kompotte, Puddings, Kremspeisen, Eis 1971; Aus der Schale geplaudert 1984), схемы вязания и вышивки (Häkellehrgang 1957; Nähen lernen leicht gemacht 1959; Kinderfasching. 12 Modelle 1978; Blütenmotive. Abplättmuster 1981; Ostermuster. Abplättmuster 1981; Minibilder gestickt 1984; Pflanzen in unserer Wohnung 1986; Manke M. Palmen. Pflanzenbuch 1989), советы по ведению домашнего хозяйства и садоводству (Pflanzen in unserer Wohnung 1967; Wohnungs ABC 1978; Haushalttips für Jung und Alt 1980; Unsere Balkonpflanzen 1988).

Трансляция норм, в первую очередь, происходила через журнал «Die Frau von heute» - печатный орган DFD - Демократического Женского Союза Германии. Его основным содержанием были отчёты о работе центрального и земельных отделений DFD, политическое воспитание. Также журнал публиковал репортажи о трудовой деятельности выдающихся работниц ГДР, отчёты о крупных культурных событиях, советы по педагогике, фасоны и выкройки женской и детской одежды, кулинарные рецепты, рассказы и выдержки из романов. Таким образом, тематически журнал определял ключевые сферы женской реализации - труд, общественную деятельность и домашние обязанности женщин.

Правопреемником «Die Frau von heute» стал журнал «Für dich». Рубрикация и содержание публикаций в 1960-х - первой половине 1970-х гг. продолжало линую журнала-предшественника. В журнале тема досуга поднималась регулярно, однако в большей степени касалась путешествий. В каждом номере темой одной из рубрик были путевые заметки или обзор достопримечательностей того или иного региона ГДР или стран народной демократии: горные курорты Гарца (Für dich 1965. № 10: 14-17), Meкленбургская Швейцария (Für dich 1965. № 40: 23-24) и др. Одной из популярных форм коллективного досуга, освещаемой в журнале, были различные фестивали, включавшие официальную часть - конференции, митинги - и полуофициальную - концерты, конкурсы, спортивные состязания. Организаторами мероприятий выступали общественные организации, чаще всего - Союз свободных немецких профсоюзов (FDGB). Ярким примером такого фестиваля, привлекавшего посетителей со всей страны, была Неделя Балтийского моря, проходившая в предместье Ростока, курорте Варнемюде, в 1958-1975 гг. Идея Недели - мирное сотрудничество государств акватории Балтийского моря и признание ГДР равноправным участником международной политики, в частности - в данном регионе. Высокий уровень организации и размах объяснялись международным статусом и стремлением соперничать с Кильской неделей - парусной регатой и масштабным праздником, который ежегодно проводился в ФРГ. В этом проявилась характерная черта искусственного соперничества и “витринного” социализма ГДР, в которой нарочито поддерживался “высокий” уровень жизни с тем, чтобы предотвратить бегство граждан на Запад. В публикациях «Für dich» посещение фестиваля предполагало для женщины выбор праздничных нарядов и причёсок и приравнивалось к светскому мероприятию (Für dich 1965. № 30: 4-5).

В проведении подобных местных фестивалей и ярмарок, частично сохранившихся в ГДР, наряду с досоциалистической эпохой, проявлялась традиционная черта немецкой культуры - выраженная локальная городская и земельная идентичность. Наиболее посещаемыми в ГДР были «Eisleber Wiesenmarkt» в Саксонии-Анхальт, фольклорный фестиваль «Vogelwiese» в Дрездене, фестиваль фонарей в Галле, традиционный для Западной Померании летний праздник «Tonnenabschlagen», крупнейший фольклор- 
ный фестиваль «Annaberger Kät» в Рудных горах и многие другие. Неизменными были рождественские и пасхальные ярмарки в Дрездене, Ростоке, Лейпциге, Герлице и других городах. Среди исследователей нет однозначного ответа на вопрос об отношении СЕПГ к локальным фестивалям, т.к., с одной стороны, посредством проведения ярмарок и масштабных гуляний происходило умиротворение населения и обмен продукцией, недоступной в условиях плановой экономики, а, с другой, - очевидно, свободные от коммунистической идеологии, фестивали укрепляли как местную идентичность, так и представления о единой в культурном плане Германии. Не организовывался в годы существования ГДР исторический фестиваль «Дни Валленштайна» в Штральзунде, постепенно потерял известность традиционный праздник встречи весны «Brezelsingen». Однако, несмотря на популярность, традиционные фестивали практически не находили отражения в республиканской прессе, в том числе в женских журналах. Исключением был ежегодный карнавал, «Fasching» или «Fastnacht», проводившийся перед началом Великого поста, и происходивший от традиционного обряда земледельческого цикла - встречи весны. На протяжении двух-трёх месяцев перед карнавалом в женской прессе публиковались разнообразные рекомендации по изготовлению карнавальных костюмов, в т.ч. совместной подготовке с детьми как форме игры и обучения навыкам шитья и оформления (Die Frau von heute 1959. № 1: 16-17; Für dich 1965. № 5: 42-46; Pramo 1965. № 1: 20-23).

Один из ключевых видов досуга, неизменно находивший отражение в журналах «Die Frau von heute» и «Für dich» - чтение. В журналах публиковались выдержки из романов и повестей авторов прошлого и современных писателей, рекомендации и анализ книжных новинок. По сравнению с рубриками, посвящёнными домашнему хозяйству, литературные обзоры и выдержки текстов занимали большее количество полос, что свидетельствует как о востребованности рубрик, так и о редакционной политике журнала. Официально популярность чтения в ГДР объяснялась успехами социалистической системы образования и массового просвещения, активной культурной политикой СЕПГ. Ряд исследователей в качестве основной причины указывает компенсаторную функцию: литература могла в определённой степени “сгладить” недовольство общества ограниченными возможностями выезда из страны (Линкс 2017: 193-204). В ГДР была организована обширная библиотечная сеть, в первые годы после объединения на вопрос о степени востребованности библиотек жители новых федеральных земель отмечали сохраняющуюся заинтересованность в посещении и больший объём прочитанной литературы. Сложно сделать однозначный вывод о наличии гендерной специфики в публикуемых отрывках. На примере номеров журнала «Für dich», изданных в 1965 г., можно отметить: наряду с текстами авторов-женщин (фрагменты романа Р. Вернер «Свыше ста гор / Über hundert Berge» (Für dich 1965. № 10-33)) и текстами, обращёнными к читательнице-женщине (рассказ Х. Зиннер «Свекровь / Die Schwiegermutter» (Für dich 1965. № 10: 28-29)), приведены фрагменты романа Ю. Брезана «Годы возмужания / Mannesjahre» (Für dich 1965. № 1-4), романа И. Кнаппе «Моя безымянная страна / Mein namenloses Land» (Für dich 1965. № 34-52), рассказ кубинского дипломата и писателя А. Байо «Иисус и повстанцы / Jesús und die Rebellen» (Für dich 1965. № 5: 28-32).

В 1960-х гг. в журнал «Für dich» добавилась программа телевизионных передач, а также краткие обзоры и обсуждения популярных программ. Кадры киноплёнки в архиве «Open memory box» часто фиксируют проведения времени у экрана, семейные 
просмотры фильмов, спектаклей, в особенности - спортивных состязаний. Значимым аспектом в рамках данной темы являлась возможность смотреть телевидение ФРГ, т.к. телевизионные приёмники в особенности в Восточном Берлине, а также на значительной части страны принимали сигнал западного телерадиовещания. Как исследователи, так и рядовые немцы после падения стены отмечали в интервью и воспоминаниях, что возможность наблюдать жизнь на Западе и не иметь шансов быть вовлечённым в неё усиливала кризис и приближала объединение государств. Просмотр западных передач был нормой, приоритетным выбором. В разделе “истории” портала «Open memory bох» респондент г-н Лаутербах отвечает на вопрос исследователя «Боялись ли вы, что это кто-то увидит?», подразумевая фиксацию в домашней кинохронике просмотра западного телевидения: «Нет, абсолютно нет» (OMB Geschichte: Herr Lauterbach). Boпрос журналиста представляется закономерным, т.к. слежка за населением, широкая сеть агентуры и практика доносительства на окружение являлись частью повседневности жителей ГДР и были обусловлены деятельностью Министерства государственной безопасности, Штази (сокр. от Ministerium für Staatssicherheit - Stasi).

Основная функция популярного журнала «Рramo» (сокр. от praktische Mode практичная мода) состояла в трансляции модных тенденций и публикации выкроек для самостоятельного изготовления одежды, что в условиях тотального дефицита промышленных товаров при социализме являлось актуальным для многих стран, ориентирующихся на советскую модель построения общественных отношений. Модели, приведённые на многих фото, в отличие от «Die Frau von heute», сняты, в основном, на нейтральном фоне, имеющем скорее художественную значимость и оттеняющем цветовую гамму одежды. Так, коллекции одного выпуска журнала, включающие пальто, жакеты, строгие деловые комплекты для полных женщин, а также домашние комплекты, могли быть представлены моделями, прогуливающимися в “берёзовом лесу” среди поваленных деревьев, в парке в модельной обуви (Pramo 1965. № 10: 4-5, 8-15, 18-19). Чаще всего выпуск был отснят в студии, где предметы - шезлонг, пляжный зонт и др., позволяли в некоторых случаях судить о функционале демонстрируемой женской одежды. Большую часть представленных в журнале изображений составляли костюмы, созданные для работы. Об этом свидетельствует крой и сдержанная цветовая гамма, более строгие фоны. Непосредственно на досуг указывает также фон модной демонстрации - чаще всего это виды города. Редко присутствуют прямые упоминания функционала в заголовке: «Создание карнавальных костюмов» (ежегодно) ${ }^{1}$, например, из подручных средств (Рramo 1965. № 1: 22-23), «Выходные платья для послеобеденного и вечернего времени» (Рramo 1965. № 10: 6-7), «Платья для похода на танцы» (Pramo 1965. № 1: 12-13). Мужская мода представлена в журнале незначительно, совместные фотосессии женщин и мужчин в студийных или реальных декорациях редки и призваны скорее сделать акцент на меняющихся модных тенденциях. На большей части фото, демонстрирующих отдых на свежем воздухе, модели-женщины изображены парами, прогуливающиеся или беседующие друг с другом (Pramo 1975. № 3-7). Это позволяет судить о том, что данные изображения были предназначены преимущественно женской аудитории и атрибутировали моду в общественном сознании исключительно женской повседневности, тем самым строго нормируя ее функциональность.

\footnotetext{
${ }^{1}$ См., напр.: Pramo. 1965-1985. № 1.
} 
Также среди рубрик представлена одежда для детей в виде повседневной сезонной, карнавальной, и для юных девушек, которая отличается пастельными тонами, неброскими цветочными принтами, однако более “смелыми” конструктивными элементами, такими как длина, вырезы, оборки. Стоит отметить, что наряду с выкройками, схемами для вязания и вышивок в модных журналах ГДР представлена неизменная страничка кулинарии - рецепты, планы питания, кухня народов мира (в основном, стран ОВД).

Изучение приводимых в журнале «Рramo» изображений позволяет уточнить составляющие транслируемого нормативного образа женщины ГДР, проводящей своё свободное время в лишённом географической локализации абстрактном “отпуске”. Неизменно веселая, утончённая, следящая за собой, она выбирает полуспортивный или спортивный лаконичный крой, с течением времени должна становиться всё более консервативной в выборе цветового решения (в отношении цвета исключением были 1980-е гг.), что маркировало нормативный переход в следующую возрастную когорту.

Журнал «Sibylle» - “журнал о моде и культуре”, издаваемый Берлинским институтом моды, затем перешедший под управление «Verlag für die Frau», нередко называли “восточным Vogue”. От зарубежного “модного глянца" журнал отличали, в первую очередь, фотографии А. Фишера, отказавшегося от студийной фотосъёмки в пользу “живых кадров”, снятых на улицах Берлина, в метро, магазинах. По сравнению с остальной женской прессой ГДР журнал не содержал колонки советов или репортажи об успехах социалистического строительства. Пережив несколько этапов в редакционной политике и отношениях с CЕПГ, в большей степени «Sibylle» оставался проводником моды, дизайна, архитектуры, живописи и графики и мало соприкасался с повседневной социалистической реальностью в плане тематики и фактической уличной моды, однако существовал в том же окружающем пространстве, в котором проживали свою повседневную жизнь жительницы Берлина, Лейпцига, Дрездена. Мир журнала стал для женщин ГДР и вдохновением, и иллюзией. Приобрести одежду, демонстрируемую моделями, было невозможно, однако журнал включал выкройки, позволяющие воспроизвести представленные фасоны (хотя приобретение ткани для воплощения модных новинок было также проблематично). Редакционная политика была ориентирована на высокую эстетику, за что журнал нередко подвергался критике со стороны власти. Так под прямым давлением цензуры в середине 1960-х гг. на страницах появились женщины-рабочие, снятые на производстве, а общая направленность публикаций должна была демонстрировать наиболее взыскательный уровень потребления на Востоке (Sibylle 1963. № 3: 4-19). Отвлечённость от проблем социалистического государства рабочих и крестьян, броское минималистичное оформление, художественная фотография, требующие существенного культурного бэкграунда кино- и литературные обзоры, небольшой тираж и всего 6 выпусков в год сделали журнал символом и носителем высокого стиля, недостижимой мечты и «нездешней» экстравагантности.

На начальном этапе существования журнала, в 1956-1961 гг. предлагаемые костюмы нередко напрямую указывали на обстоятельства ношения. Показательны развороты «Von früh bis spät» (C утра до вечера, буквально: C раннего до позднего) (Sibylle 1959. № 1: 5-7), где к Международному женскому дню для работающих женщин были представлены несколько готовых образов для различных ситуаций: для торжественного случая, приёма гостей, посещения выставки, утренней гимнастики, уборки 
дома, посещения родительского консультативного комитета, работы, ухода за садом, посещения магазина. В сопроводительной статье подчёркивалось, что и на работе, и на отдыхе залогом уверенности в себе является безупречный внешний вид. В каждом номере был опубликован “модный репортаж”, посвящённый событию и соответствующему набору ансамблей одежды для участвующей в нём женщины: ежегодная велогонка Берлин-Варшава, прогулка на яхте, рождественские торжества и др.

В 1960-е гг. содержание публикаций менялось, всё больше обращаясь к моде, дизайну, искусству и уходя от быта. В 1970 - 1980-е гг. трансляция досуга женщин в зависимости от функционального назначения одежды в «Sibylle» представляется неочевидной, т.к. модели скорее демонстрировали художественную ценность образа, экспериментальный крой, нежели его практическое применение. Однако, исходя из тематики публикаций, можно сделать вывод, что досуг женщины, мир которой демонстрировал журнал, включал посещение театра, кино и художественных выставок, чтение, увлечение музыкой и спортом. Изготовление одежды в рамках данного жизненного стиля было представлено именно как творчество, вид искусства, а не как необходимость. Выращивание комнатных цветов, приправ и лекарственных растений представлялось как форма украшения пространства и приверженность здоровому образу жизни. Именно журнал «Sibylle» в большей степени транслировал образ “новой” эмансипированной женщины, делал акцент на индивидуальности, в том числе в реализации досуга, однако подобный подход основывался на ориентации на западную прессу и, оставаясь эталоном, мало соотносился с социалистической реальностью.

Источник, позволяющий анализировать пространство проживания повседневной жизни женщин в ГДР, обладающий особенно высокими информационными возможностями при исследовании досуга - семейные кинохроники, Schmalfilme - видео, снятые на узкую плёнку (8 и 8, 5 мм). В августе-сентябре 2019 г. в интернете был запущен проект «Open memory box» (Открытая коробка памяти) - самая большая в мире оцифрованная коллекция частных видеозаписей. Работа с материалами проекта позволяет исследовать досуг методами визуальной антропологии, анализировать наиболее значимые моменты, признанные таковыми жителями ГДР - кадры с детьми, первые шаги и первые дни в школе, домашние праздники, отдых в саду и на даче, путешествия. Важно подчеркнуть, что сама по себе запись семейной кинохроники также относилась к специфическим для ГДР практикам досуга, скажем, у граждан СССР технических возможностей для этого не было и массовым явлением ведение домашней киносъемки не стало. Как характерную черту женского досуга в ГДР домашние кинохроники запечатлели создатели знакового художественного фильма о падении социалистического немецкого государства «Гуд бай, Ленин» (реж. В. Беккер, 2003).

Привлечение семейных кинохроник позволяет исследователю обратиться к такой значимой в этнологии проблеме как трансформация праздничной культуры. Исследователи отмечают в ГДР последовательное стремление сформировать гражданскую религию, являвшееся следствием идеологического противоборства СЕПГ и местных церквей (Neubert 1998; Lange 2004). Данное решение проявлялось в организации светских ритуалов, коррелирующих с обрядами жизненного цикла - рождением, переходом во взрослую жизнь и свадьбой. Внедрение светской альтернативы имянаречению и крещению не получило поддержки в обществе ГДР, как и социалистический брак, заключавшийся в торжественной атмосфере в форме церемонии в кругу товарищей по работе или общественной организации, а не в церкви и даже не в ор- 
ганах ЗАГС. В то же время «Jugendweihe», (Посвящение молодёжи) - обряд инициации, переход из подросткового возраста во взрослый, обычно в возрасте 14 лет, организованный в конце XIX в. среди сторонников Свободного религиозного движения как обряд, альтернативный миропомазанию, или конфирмации, широко распространённый в Веймарской республике, был воспринят и в ГДР. Форма мероприятия была изменена, религиозная составляющая устранялась, сохранялся гуманистический посыл, обращение к молодёжи с наставлениями о жизни в социалистическом обществе. Исследователи указывают на обязательность данного мероприятия и возможные санкции в случае неучастия. В зале театра или ином помещении, вмещавшем большое количество посетителей, девушки и юноши в сопровождении родственников давали клятву посвящения социалистическому государству, получали в дар от пионеров цветы, от представителя властей - книгу, содержащую основные необходимые мировоззренческие установки строителя социализма. В современных немецких СМИ, анализирующих сохранившийся в новых федеральных землях ритуал посвящения молодёжи, встречаются свидетельства участников «Jugendweihe». Среди них воспоминания Катрин Линдер, отмечавшей, что в 1986 г. самой большой проблемой был праздничный гардероб, т.к. отделы молодёжной моды не предполагали особого выбора: «Я так гордилась той синей юбкой!» (Hübscher 2019). Ceмейные кинохроники позволяют увидеть “домашнее” продолжение общественного торжества. На записях подростки в сопровождении членов семьи и друзей покидают зал, часто снят процесс коллективной фотосъёмки участвовавших в посвящении: преимущественно белые или светлые платья и праздничные укладки волос у девушек, небольшие букеты цветов в руках (OMB Archiv: 078-13; OMB Archiv: 099-14; OMB Archiv: 099-14; OMB Archiv: 088-10; OMB Archiv: 104-02;). Журнал «Sibylle», например, предлагал в одном из номеров четыре эскиза - образы для торжества, ориентированные на различный вкус (Sibylle 1959. № 1: 65). Семья отправлялась в кафе, домой или на прогулку. Дома мероприятие продолжалось чаепитием или застольем, беседами в кругу многих разнопоколенных родственников (OMB Archiv: 078-13; OMB Archiv: 099-14; ОМВ Archiv: 048-09). Отсутствие звука не дают возможность судить о содержании бесед, однако их неформальный, внутрисемейный характер очевиден. В 1980-е гг. появляются единичные записи вечеринок молодёжи без старших родственников (ОМВ Archiv: 049-06), однако в исследованиях отмечается, что для подростков возможность отметить посвящение в кругу друзей составляла основное содержание праздника. Среди обрядов жизненного цикла в женских журналах ГДР упоминались, в основном, свадьбы, причем исключительно в вопросе внешнего вида: платье, туфли, укладка волос (Die Frau von heute 1959. № 20: 16-17).

Семейные кинохроники также позволяют исследовать пространство реализации досуга (в особенности это касалось путешествий), которое было ограничено. Туристические поездки за рубеж, организацией которых занималось Государственное туристическое бюро ГДР, были возможны исключительно в соцстраны. Существовала также возможность приобретения недорогих туристических путёвок по стране и за рубеж для населения моложе 28 лет по линии государственного бюро в рамках направления «Jugendtourist». Внутренний туризм, однако, едва ли был способен удовлетворить потребности населения и также был сопряжён со сложностями. Часто при посредничестве Союза свободных немецких профсоюзов (FDGB) или самих предприятий организовывались туристические поездки, поездки в дома отдыха для трудящих- 
ся. Места в домах отдыха распределялись в основном централизованно и возможность выбрать место отдыха самостоятельно, а значит отправиться без коллег, стоила существенных денег. Кроме того, отели и гостиницы ГДР были в основном ориентированы на иностранных туристов, стоимость проживания была значительной. Альтернативная возможность - поездка в палаточные лагеря, кемпинги, большое количество которых было организовано на побережье Балтийского моря. С опорой на домашние кинохроники можно сказать, что популярными местами отдыха были пляжи побережья Балтийского моря, остров Рюген, горы Гарца, пляжи Херингсдорфа и др. На кадрах по запросам “путешествие”, “туризм”, “заграница” представлены групповые поездки с коллегами, реже - путешествия женщин в компании подруг или семьи.

Семейная пара Лаутербах, респонденты проекта, с ностальгией рассказывают о туристических поездках, организованных бригадой, в которой работал супруг. В течение года часть зарплаты и премий откладывалась в общую кассу, и каждую зиму предпринималось совместное путешествие членов бригады с семьями. «Мы хорошо жили. Мы не могли пожаловаться... < .. > Где эти дни? Это было прекрасно. Мы радовались, всё проходило отлично < . . > С нами ездили доценты из университета Гумбольдта». На плёнке сохранились поездки в Берлин и Чехию, причём г-н и г-жа Лаутербах уточняют, что сложностей с пересечением границы не было: «С чехами и поляками все было иначе. Насколько это было открыто. И мы поехали туда без проблем. Но вы никогда не добрались бы до внутренней границы Германии» (OMB Geschichte: Herr Lauterbach; OMB Geschichte: Frau Lauterbach). Это же подтверждает и другая участница проекта, отмечавшая, что в студенческие времена, в начале 1970-х гг, в Прагу с супругом они могли доехать автостопом с «хлебом и колбасой в сумке, и с планами ночевать под мостом» (OMB Geschichte: Ich bereue es). Первое свидетельство демонстрирует своеобразную тоску по коллективной идентичности гражданок бывшей ГДР, которая формировалась и закреплялась в процессе досуговых практик.

Возможность путешествовать за рубеж для жителей ГДР, действительно, изменилась после 1972 г. с достижением соглашения о безвизовом режиме со странами ОВД. Без согласования можно было поехать в Чехословакию в 1972-1989 гг. и в Польшу в 1972-1980 гг. В остальных случаях необходимо было заранее согласовать в отделе регистрации Народной полиции поездку, впоследствии иметь с собой специально оформленное подтверждение («Reiseanlage für den visafreien Reiseverkehr» - система поездок для безвизовых путешествий). Поездки в Болгарию, Румынию и Венгрию обычно согласовывались без дополнительных действий, хотя не существовало никаких гарантий и мог последовать немотивированный отказ полиции.

Путешествие в СССР было возможно в составе организованной группы или по одобренному приглашению, однако в ряд регионов приглашение не могло быть оформлено. Кроме того, запрещено было покидать город, указанный в маршруте. В неофициальной практике существовала ещё одна возможность поездки в СССР, «Unerkannt durch Freundesland», или «UnF» - «необнаруженные в дружественной стране»: по пути в Румынию для граждан ГДР допускалось транзитное пребывание на территории СССР в течение двух-трёх дней и, пользуясь этим, путешественники отправлялись дальше в Союз, добираясь до крайнего Севера, Камчатки, границ с Китаем. По возвращении на советско-румынской границе требовалось уплатить незначительный штраф, по воспоминаниям в 1980-х гг. он составлял 10 рублей. Участники подобных поездок отмечают на страницах специально созданного интер- 
нет-портала (Unerkannt durch Freundesland), в сборниках воспоминаний и путевых заметок (Kuhbandner, Oelker 2010), что количество таких путешествий невозможно зафиксировать статистикой, но оно исчислялось тысячами в период 1972-1989 гг.

Одна из авторов-составителей сборников, Корнелия Клаус, в своём документальном фильме «Необнаруженные в дружественной стране» приводит интервью участников нелегальных поездок в Союз о своих уловках, попытках скрыться от преследования сотрудниками КГБ. Все респонденты в фильме, как и большинство авторов путевых заметок и впечатлений, приведённых в сборниках - мужчины, занимавшиеся в прошлом альпинизмом. Однако воспоминания И. Бенинг и К. Калиес (Böhning 127-136; Kalies 358-373), два женских текста, свидетельствуют о том, что среди нелегальных путешественников пусть и в меньшем количестве, но постоянно присутствовали девушки, также альпинистки. По воспоминаниям, поездки были сопряжены с огромным риском как со стороны государственных органов (оказаться “пойманными” КГБ, быть депортированными в ГДР с запретом выезда на год и более), так и по иным причинам - из-за незнания языка, необходимости путешествовать автостопом и находить средства к существованию и т.д.

При всех вышеописанных сложностях, а также в связи с недостатком денежных средств большинство жителей ГДР проводили свободное время в выходные и в отпуске в коротких поездках на базы отдыха и пляжи. В 1940-е гг. в домашних кинохрониках - прогулки в парках и скверах, поездки в замок Айленбург, к озеру Вёрлитцер (OMB Archiv: 145-09). В следующем десятилетии на плёнке сохраняется большее разнообразие путешествий - прогулки на лодках и экскурсионных катерах, лыжные походы, а также фиксируется больше маршрутов - курорты Балтийского моря, леса Тюрингии, Эльбские Песчаниковые горы в Саксонской Швейцарии, замок Вартбург, комплекс Цвингер в Дрездене, дворец Сан-Суси в Потсдаме и др. (OMB Archiv: 00109; OMB Archiv: 033-20; OMB Archiv: 037-12; OMB Archiv: 098-12; OMB Archiv: 14207). Позднее на плёнке всё меньше путешествий по отношению к общему количеству записей, камеры становятся доступнее и чаще фиксации подлежат менее уникальные события, домашние архивы пополняются записями повседневного быта. Встречаются единичные случаи поездки в горы Кавказа, на Кубу, в Алжир, в Китай. По-прежнему наиболее популярное место отдыха в стране - побережье Балтийского моря.

Особое значение имел отдых на даче - небольшом земельном участке неподалёку от города, часто не отделённом забором от соседей и снабжённом летним домиком и хозяйственными постройками. Недостаточный ассортимент продуктов, доступных для приобретения, а также возможность дополнительного заработка при розничной продаже выращенных овощей и трав делали садоводство и огородничество на даче сравнительно популярным видом условно досуговой деятельности, в особенности для граждан пенсионного возраста (OMB Archiv: 005-03; OMB Archiv: 009-31; OMB Archiv: 009-35; OMB Archiv: 013-21). Однако основной причиной популярности дач исследователи называют возможность почувствовать себя в частном, относительно свободном от регулярного контроля со стороны Штази пространстве, проведение времени в котором не регламентировано государством.

На дачах снята значительная часть хроник, участники которых проводят свободное время в кругу семьи или друзей. Основные сюжеты - игры с детьми, принятие солнечных ванн, домашние праздники за накрытым столом, приготовление на гриле колбасок (OMB Archiv: 013-14; OMB Archiv: 065-05; OMB Archiv: 071-04). Именно 
на дачах чаще возможно зафиксировать значимую для жителей ГДР форму досуга занятия любительским спортом: бег, плавание, игры с мячом и т.д. (OMB Archiv: 021-18; OMB Archiv: 013-14; OMB Archiv: 079-24). Девиз государства, озвученный В. Ульбрихтом в 1959 г., «Jedermann an jedem Ort - einmal in der Woche Sport» (буквально: каждый в каждом месте - раз в неделю спорт) (Браун 2017: 180), являлся частью масштабной политики популяризации профессионального и любительского спорта. В городах была доступна возможность бесплатно или за символическую плату заниматься в различных секциях и группах в различных видах спорта.

Безусловно, в зависимости от социального статуса, местом отдыха на природе могли быть и загородные дома с крупными участками. Одна из респонденток портала, комментируя записи отдыха с семьёй в местечке Дольгенбродт, отмечает, что участок был получен отцом ещё до возведения стены; обладание загородным домом и квартирой улучшенной планировки в Берлине составляло основную привилегию врачей в ГДР, т.к. заработная плата не была высокой. Героиня объясняет подобное положение необходимостью удержать оставшуюся часть интеллигенции от отъезда в ФРГ. Мать респондентки - детский врач, отец - главный врач в больнице района Панков Берлина. Среди присутствовавших на записи респондентка отметила домработницу семьи, сообщая, что занятость родителей, в особенности ночные смены, не позволяла достаточно времени уделять дому, и на протяжении всего детства героини у неё были няня и домработница. Застолья и чаепития, купания в озере у дома и рыбалка, занятия героев хроники, в основном - женщин, коллег-врачей. «Мама всегда ложилось на причале [на озере у дома] и загорала. Конечно, она много занималась домашним хозяйством, но кроме того садилась на причале в хорошую погоду», рассказывает героиня. На видео также снят ежегодный визит коллег отца, становившийся причиной домашнего торжества: «Все праздновали и пели, и конечно плавали и катались на лодке. Пели песни собственного сочинения, например о враче, поехавшим в Венгрию и скрывшимся там». Исходя из данного рассказа, замечаний и эмоций героини, с горечью отмечавшей, что на данном видео её мама часто смеётся, но воспоминания сохранили иной, менее жизнерадостный образ, можно отметить, что возможность такого отдыха, в доме в 60 км от Берлина, была для семьи нечастой (OMB Geschichte: Meine Ente).

Также в 1950-х гг. на плёнке появляются нудистские пляжи - допустимое в немецкой культуре явление, не политизированное и не регламентируемое специально (OMB Archiv: 002-25; OMB Archiv: 008-22; OMB Archiv: 008-24; OMB Archiv: 009-09; OMB Archiv: 028-01; OMB Archiv: 042-08; OMB Archiv: 042-05). Движение «FKK» (Freikörperkultur, культура свободного тела) возникло в Германии в конце XIX в., пропагандируя единение с природой, здоровый образ жизни, занятия спортом. В период Третьего Рейха нудистские пляжи были запрещены, после Второй Мировой войны деятельность движения продолжилась. Большое количество мест отдыха на побережье Балтийского и Северного морей, а также на берегах местных дачных водоемов были снабжены табличкой «FKK», что было нетипично для СCCP и других социалистических стран. Движение в ГДР не только не противоречило государственному запросу, но и коррелировало с установкой «Jedermann an jedem Ort einmal in der Woche Sport». Существует мнение, объясняющее приверженность FKK в ГДР своеобразной протестной реакцией немцев на тотальный контроль и слежку в государстве. Так или иначе, об отношении к нудизму как к норме можно сделать 
вывод, анализируя записи 1960 - 1970-х гг. - камера снимает с близкого расстояния обнажённые фигуры мужчин и женщин, играющих в волейбол, загорающих, прогуливающихся, играющих с детьми - сюжеты скорее посвящены фиксации привычного досуга, в который вовлечён оператор, нежели съёмке “редкости”.

Подводя итог, можно отметить, что юридическое равноправие женщин, зафиксированное в конституции 1949 г. и отраслевых законах в 1950 г., а также вовлечение женщин в производственную деятельность позволило на официальном и, во многом, реальном уровне устранить ограничение прав и областей реализации женщин, в т.ч. в сфере досуга. Однако обобщённые заявления СЕПГ о том, что женщина в ГДР, трудящаяся на благо общества, ставшая финансово независимой, творчески освобождённая, может строить свою жизненную траекторию осознанно, не включали в себя упоминаний о том, как необходимость одновременно с трудовой деятельностью и постоянным повышением квалификации выполнять обязанности по дому сказывалась на «осознанно выбранной траектории» и проявлялась, в частности, в объёме и содержании свободного времени женщин.

На основании анализа двух типов и видов источников - материалов женской прессы ГДР, а также семейных кинохроник - можно отметить, что как на уровне трансляции нормативного образа, так и на уровне реализации личных целей в области свободного времени, основной объём досуговых практик реализуется женщинами в семье. Приемлемые формы условно личного досуга в женской прессе - кулинария и домашнее изготовление одежды - позиционировались как сугубо женская деятельность, выполнение которой предполагало творческий подход, трудоёмкость процесса не отрицалась. Свободное от ведения домашнего хозяйства время журналы рекомендовали посвятить чтению, путешествиям по территории ГДР, посещению театров и кинотеатров, позднее - телевидению. Среди форм публичного досуга в прессе предлагалось посещение массовых мероприятий, в основном - демонстраций, спортивных фестивалей, ярмарок. Специфика содержания публикаций каждого из популярных журналов позволяет сделать вывод как об обязательных предписываемых формах досуга, фактически являющихся составляющими неоплачиваемого женского труда, так и о различиях в образах и жизненных стратегиях читательниц. Семейные кинохроники, в свою очередь, позволяют выявить те формы реализации досуга, которые практически не упоминались в женских журналах - проведение свободного времени на дачах, отдых на пляжах, в том числе нудистских, участие в фольклорных фестивалях. Представляется значимым тот факт, что семейные кинохроники не фиксируют в указанных формах досуга, не относящихся к ведению домашнего хозяйства, очевидной гендерной специфики: большая часть практик реализуется мужчинами и женщинами, зачастую совместно.

\section{Источники и материалы}

Aus der Schale 1984 - Aus der Schale geplaudert. Leipzig: Verlag für die Frau, 1984. Blütenmotive 1981 - Blütenmotive. Abplättmuster. Leipzig: Verlag für die Frau, 1981.

Böhning 2011 - Böhning I. Vom Wohnkomplex 5 E in Honwoy ans Schwarze Meer // Klauß C.,

Böttcher F. (Hrsg.). Unerkannt durch Freundesland. Illegale Reisen durch das Sowjetreich.

Lukas Verlag, Berlin 2011. 127-136.

Die Frau von heute 1959 - Die Frau von heute. 1959. № 1, № 20.

Feines 1961 - Feines Gebäck zu Kaffee und Tee. Über 100 Rezepte. Leipzig: Verlag für die Frau, 1961. Für dich 1965 - Für dich. 1965. № 1-52. 
Häkellehrgang 1957 - Häkellehrgang. Leipzig: Verlag für die Frau, 1957.

Hübscher 2019 - Hübscher Ch. Jugendweihe in der DDR und heute in Ostdeutschland: Die Ersatzreligion // Spiegel. 07.08.2019. https://www.spiegel.de/geschichte/ersatz-religion-jugendweihein-der-ddr-und-heute-in-ostdeutschland-a-1280724.html (Datum der Behandlung: 19.05.2020).

Kalies 2011 - Kalies K. Am kurzen Rock uns an hohen Schuhen hat es nicht gelegen // Klauß C., Böttcher F. (Hrsg.). Unerkannt durch Freundesland. Illegale Reisen durch das Sowjetreich. Lukas Verlag, Berlin 2011. 358-373.

Kinderfasching 1978 - Kinderfasching. 12 Modelle. Leipzig: Verlag für die Frau, 1978.

Kochen 1966 - Kochen für junge Leute. Leipzig: Verlag für die Frau, 1966.

Manke 1989 - Manke M. Palmen. Pflanzenbuch. Leipzig: Verlag für die Frau, 1989.

Minibilder 1984 - Minibilder gestickt. Leipzig: Verlag für die Frau, 1984.

Nähen 1959 - Nähen lernen leicht gemacht. Leipzig: Verlag für die Frau, 1959.

Neumann 1980 - Neumann L. Haushalttips für Jung und Alt. Leipzig: Verlag für die Frau, 1980.

OMB Archiv - Open Memory Box. Archiv: 001-09, 002-25, 005-03, 008-22, 009-09, 009-31, 009-

35, 013-14, 013-21, 021-18, 028-01, 033-20, 037-12, 042-05, 042-08, 048-09, 049-06, 065-05, 071-04, 078-13, 078-13, 079-24, 088-10, 098-12, 099-14, 099-14, 099-14, 104-02,142-07, 14509. https://open-memory-box.de/archive (Datum der Behandlung: 19.05.2020).

OMB Geschichte: Frau Lauterbach - Open Memory Box. Geschichte: Frau Lauterbach. https:// open-memory-box.de/stories/mrs-lauterbach (Datum der Behandlung: 19.05.2020).

OMB Geschichte: Herr Lauterbach - Open Memory Box. Geschichte: Herr Lauterbach. https:// open-memory-box.de/stories/mr-lauterbach (Datum der Behandlung: 19.05.2020).

OMB Geschichte: Ich bereue es - Open Memory Box. Geschichte: Ich bereue es. https://open-memory-box.de/stories/my-ducky (Datum der Behandlung: 19.05.2020).

OMB Geschichte: Meine Ente - Open Memory Box. Geschichte: Meine Ente. https://open-memory-box.de/stories/i-regret-it (Datum der Behandlung: 19.05.2020).

Ostermuster 1981 - Ostermuster. Abplättmuster. Leipzig: Verlag für die Frau, 1981.

Pflanzen 1967 - Pflanzen in unserer Wohnung. Leipzig: Verlag für die Frau, 1967.

Pflanzen 1986 - Pflanzen in unserer Wohnung. Leipzig: Verlag für die Frau, 1986.

Pramo 1965 - Pramo. 1965. № 1, № 10.

Pramo 1975 - Pramo. 1975. № 3-7

Sibylle 1959 - Sibylle 1959. № 1.

Sibylle 1963 - Sibylle 1963. № 3.

Süßes 1971 - Süßes: Kompotte, Puddings, Kremspeisen, Eis. Leipzig: Verlag für die Frau, 1971.

Transit 2010 - Transit. Illegal durch die Weiten der Sowjetunion. Erlebnisse, Tagebuchaufzeichnungen, mit zahlreichen Fotos und Karten. Hrsg. von Jörg Kuhbandner und Jan Oelker. Radebeul, 2010.

Unerkannt - Unerkannt durch Freundesland. http://www.unerkanntdurchfreundesland.de/UdF/Unerkannt_durch_Freundesland.html (Datum der Behandlung: 11.04.2020).

Unser 1970 - Unser großes Kochbuch. Leipzig: Verlag für die Frau, 1970.

Unsere 1988 - Unsere Balkonpflanzen. Leipzig: Verlag für die Frau, 1988.

Wohnungs 1978 - Wohnungs ABC. Leipzig: Verlag für die Frau, 1978.

\section{Научная литература}

Белова A.B. Интернациональная дружба по переписке как феномен повседневности школьниц в социалистических обществах 1980-х годов (на примере ГДР и СССР) // Повседневная жизнь при социализме. Немецкие и российские подходы / под ред. Я. К. Берендса, В. Дубиной, А. Сорокина, с участием Е. Аконян. Москва: Политическая энциклопедия, 2015. C. 226-246.

Белова А.В. Концепт «интернациональная дружба» в идеологии и повседневности позднесоциалистических обществ ГДР и СССР // Вестник Тверского государственного университета. Серия: История. 2018. № 1. С. 4-19. 
Берендс Я.К., Дубина В., Сорокин А. (под.ред.). Повседневная жизнь при социализме. Немецкие и российские подходы. Москва: Политическая энциклопедия, 2015. $271 \mathrm{C}$.

Браун Ю. «Раз в неделю всяк из нас спорту посвяти хоть час». Триумф и иллюзия спорта в ГДР // ГДР: миролюбивое государство, читающая страна, спортивная нация? / ред.-сост. Т. Гроссбёльтинг: пер. с нем. Москва: Мысль, 2017. С. 175-182.

Будде Г. Эмансипированное общество // ГДР: миролюбивое государство, читающая страна, спортивная нация? / ред.-сост. Т. Гроссбёльтинг: пер. с нем. Москва: Мысль, 2017. С. 94-112.

Линкс К. ГДР - страна читателей // ГДР: миролюбивое государство, читающая страна, спортивная нация? / ред.-сост. Т. Гроссбёльтинг: пер. с нем. Москва: Мысль, 2017. С. 193-204.

Мухина И.Н. Социально-правовое положение женщин в Германской демократической республике. Вестник Череповецкого государственного университета. 2013. № 1. Т. 2. С. 32-35.

Понукалина О.В. Досуг в теоретическом дискурсе социологии: подходы к исследованию // Вестник Поволжского института управления. 2017. Т. 17. № 6. С. 83-89.

Пфау-Эффингер Б. Культурные перемены и семейная политика в Восточной и Западной Германии // Социологические исследования. 2003. № 10. С. 78-87.

Сидорчук И.В. Цели и перспективы истории досуга // Историческая психология и социальная история. 2015. № 2. С. 174-186.

Хорольская M.B. «Чтобы женщина могла совмещать свои задачи гражданки и трудящейся со своим долгом жены и матери»: отношение общества и государства к проблеме соотношения материнства и женской занятости в ФРГ, ГДР и объединенной Германии // Материнство и отцовство сквозь призму времени и культур. Материалы Девятой международной научной конференции РАИЖИ и ИЭА РАН. Москва, 2016. Т. 1. С. 89-92.

Bock G. Frauen in der europäischen Geschichte. München: C. H. Beck, 2000. 393 S.

Dumazedier J. The sociology of leisure. Amsterdam: Elsevier, 1974.

Kaminsky A. Frauen in der DDR. Berlin, 2016. 320 S.

Lange I. Von der Wiege bis zur Bahre. Zur Geschichte Sozialistischer Feiern zu Geburt, Ehe und Tod in der DDR // Kulturation. Online Journal für Kultur, Wissenschaft und Politik. № 1. 2004. http://www.kulturation.de/ki_1 thema.php?id=57 (Datum der Behandlung: 11.04.2020).

Maser P. Die Kirchen in der DDR. Bonn: Bundeszentrale für politische Bildung, 2000. 426 S.

Meier A. Jugendweihe - Jugendfeier. Ein deutsches nostalgisches Fest vor und nach 1990. München: Deutscher Taschenbuch Verlag, 1998. 274 S.

Neubert E. Geschichte der Opposition in der DDR 1949-1989. Berlin: Ch. Links Verlag, 1998.

\section{References}

Belova, A.V. 2015. Internatsional'naia druzhba po perepiske kak fenomen povsednevnosti shkol'nits v sotsialisticheskikh obshchestvakh 1980 godov (na primere GDR i SSSR) [Penpal international friendship as a phenomenon of everyday life of schoolgirls in socialist societies of the 1980s (on the example of the GDR and the USSR)]. In Povsednevnaia zhizn' pri sotsializme. Nemetskie $i$ rossiiskie podkhody [Everyday Life Under Socialism: German and Russian Approaches], edited by Ia.K. Berends, V. Dubina and A. Sorokin, 226-246. Moscow: Politicheskaia entsiklopediia.

Belova, A.V. 2018. Kontsept «internatsional'naia druzhba» v ideologii i povsednevnosti pozdnesotsialisticheskikh obshchestv GDR i SSSR [The concept of «international friendship» in the ideology and everyday life of the late socialist societies of the GDR and the USSR]. Vestnik Tverskogo gosudarstvennogo universiteta 1: 4-19.

Berends, Ia.K., V. Dubina and A. Sorokin eds. 2015. Povsednevnaia zhizn' pri sotsializme. Nemetskie i rossiiskie podkhody [Everyday Life Under Socialism: German and Russian Approaches]. Moskow: Politicheskaia entsiklopediia.

Bock, G. 2000. Frauen in der europäischen Geschichte [Women in European history]. München: C.H. Beck.

Braun, J. 2017. «Raz v nedeliu vsiak iz nas sportu posviati khot' chas». Triumf i illiuziia sporta v 
GDR [«Once a week, all of us dedicate at least an hour to sports». The triumph and illusion of sports in the GDR] In: GDR: miroliubivoe gosudarstvo, chitaiushchaia strana, sportivnaia natsiia? [GDR: a peace-loving state, a reading country, a sporting nation?], edited by Th. Großbölting, 175-182. Moskow: Mysl'.

Budde, G. 2017. Emansipirovannoe obshchestvo [Emancipated Society] In GDR: miroliubivoe gosudarstvo, chitaiushchaia strana, sportivnaia natsiia? [GDR: a peace-loving state, a reading country, a sporting nation?], edited by Th. Großbölting, 94-112. Moskow: Mysl'.

Dumazedier J. 1974. The sociology of leisure. Amsterdam: Elsevier.

Kaminsky, A. 2016. Frauen in der DDR [Women in GDR]. Berlin.

Khorolskaya M.V. 2016. "Chtoby zhenshchina mogla sovmeshchat' svoi zadachi grazhdanki i trudiashcheisia so svoim dolgom zheny i materi»: otnoshenie obshchestva i gosudarstva k probleme sootnosheniia materinstva i zhenskoi zaniatosti v FRG, GDR i ob"edinennoi Germanii [«That woman could combine their task of working with the citizen and his duty to his wife and mother»: the attitude of society and the state to the problem of the relation of motherhood and women's employment in West Germany, East Germany and unified Germany]. In: Materinstvo i ottsovstvo skvoz' prizmu vremeni i kul 'tur. Materialy Deviatoi mezhdunarodnoi nauchnoi konferentsii RAIZhI i IEA RAN [Motherhood and fatherhood through the prism of time and culture. Proceedings of the Ninth international scientific conference RAWHR (Russian Association of Women's History Researchers) and IEA RAS] Vol. 1, 89-92. Moscow.

Lange, I. 2004. Von der Wiege bis zur Bahre. Zur Geschichte Sozialistischer Feiern zu Geburt, Ehe und Tod in der DDR [From the cradle to the stretcher. On the history of socialist celebrations of birth, marriage and death in the GDR]. Kulturation. Online Journal für Kultur, Wissenschaft und Politik 1. http://www.kulturation.de/ki_1_thema.php?id=57 (Datum der Behandlung: 11.04.2020).

Links, Ch. 2017. GDR - strana chitatelei [GDR - the country of readers] In: Großbölting Th.(ed.). GDR: miroliubivoe gosudarstvo, chitaiushchaia strana, sportivnaia natsiia? [GDR: a peace-loving state, a reading country, a sporting nation?], 193-204. Moskow: Mysl'.

Maser, P. 2000. Die Kirchen in der DDR [The churches in the GDR]. Bonn: Bundeszentrale für politische Bildung.

Meier, A. 1998. Jugendweihe - Jugendfeier. Ein deutsches nostalgisches Fest vor und nach 1990 [Youth Consecration - Youth Celebration. A German nostalgic Festival before and after 1990]. München: Deutscher Taschenbuch Verlag.

Mukhina, I.N. 2013. Sotsial'no-pravovoe polozhenie zhenshchin v Germanskoi demokraticheskoi respublike [Social and legal status of women in the German Democratic Republic]. Vestnik Cherepovetskogo gosudarstvennogo universiteta 1(2): 32-35.

Neubert, E. 1998. Geschichte der Opposition in der DDR 1949-1989 [History of the opposition in the GDR 1949-1989]. Berlin: Ch. Links Verlag.

Pfau-Effinger, B. 2003. Kul'turnye peremeny i semeinaia politika v Vostochnoi i Zapadnoi Germanii [Cultural Change Family Policy in East Germany]. Sotsiologicheskie issledovaniia 10: $78-87$.

Ponukalina, O.V. 2017. Dosug v teoreticheskom diskurse sotsiologii: podkhody k issledovaniiu [Leisure in the theoretical discourse of sociology: research approaches]. Vestnik Povolzhskogo instituta upravleniia 17 (6): 83-89.

Sidorchuk, I.V. 2015. Tseli i perspektivy istorii dosuga [Goals and perspectives of leisure history]. Istoricheskaia psikhologiia $i$ sotsial'naia istoriia 2: 174-186. 
Tyurenkova, Darya $O$.

\section{Anthropology of Women's Leisure in the GDR}

The article discusses the anthropology of women's leisure activities in the German Democratic Republic. Women's free time in a totalitarian society is defined as quasi-leisure, conventionally divided into public leisure, associated with state mass events, and personal leisure, the content of which was mainly determined by women. Factors that determine the amount of time free from labor and social activities were identified. An analysis of high informative sources, such as women's periodicals and family documentaries of the GDR, allowed to identify aspects of rationing leisure practices by the state and the nature of public response to propaganda methods. The female press is considered as a mechanism for transmitting the normative image of a woman; the content and specifics of publications on free time in various magazines are revealed. The study of family documentaries published on the Internet within the "Open Memory box» - a GDR-specific project, allowed to identify the most common and significant forms of women's leisure activities. Among them there is a unique German tradition of «Freikörperkultur», a free-body culture preserved under socialism. Such forms of leisure activities as external and internal tourism, as well as spending time in the countryside, is analyzed in the context of submission and willfulness strategies within restrictions on freedom of movement under the SED dictatorship. Particular attention is paid to the transformation of the traditional German festival culture, as well as the introduction of «new» socialist holidays, including alternative forms of life cycle rites (for example a widely-used rite of passage for youth). Components of the international image of GDR, such as the «reading country» or the «sports nation», are analyzed based on women's periodicals and family documentaries.

Keywords: leisure, leisure history, anthropology of leisure, women's leisure, women's everyday life, women's history, East Germany 